BioLink

JURNAL BIOLOGI LINGKUNGAN, INDUSTRI, KESEHATAN

Available online http://ojs.uma.ac.id/index.php/biolink

\title{
SKRINING FITOKIMIA DAN UJI AKTIVITAS ANTIBAKTERI EKSTRAK ETANOL DAUN SANGITAN (Sambucus javanica Reinw) TERHADAP PERTUMBUHAN BAKTERI Eschericia coli DAN Salmonella thypi
}

\section{Scrining Fitochemism And Test of Antibacterial Activity of Extract Etanol Leaf Leaves (Sambucus javanica Reinw) on Growth Bacteria Eschericia coli and Salmonella thypi}

\author{
Eva Sartika Dasopang \\ Fakultas Farmasi, Universitas Tjut Nyak Dhien \\ Gg. Rasmi No.28, Sei Sikambing C. II, Medan Helvetia, Kota Medan \\ *Corresponding author: E-mail: evasartikadasopang@vahoo.com
}

\begin{abstract}
Abstrak
Daun sangitan (Sambucus javanica Reinw) sering dijumpai tetapi kurang diperhatikan. Bagian daun dari tumbuhan sangitan digunakan untuk mengobati pembengkakan, insektisida, antidiare, antiinfeksi, luka, menghaluskan kulit karena mengandung senyawa kimia flavonoid, glikosida, glikosida antrakinon, saponin, steroid/ triterpenoid dan tanin. Hasil skrining ekstrak etanol daun sangitan (Sambucus javanica Reinw) mengandung senyawa alkaloid, flavonoid, glikosida, glikosida antrakinon, saponin, steroid/triterpenoid dan tanin. Ekstraksi daun sangitan dilakukan dengan maserasi menggunakan etanol 96\%. Pengujian aktivitas antibakteri ekstrak etanol daun sangitan dilakukan secara in vitro dengan metode difusi sumuran dengan konsentrasi 500, 400,300,200 dan 100 $\mathrm{mg} / \mathrm{ml}$. Penelitian ini menggunakan cotrimosazole sebagai pembanding dan etanol 96\% sebagai kontrol negatif. Ekstrak etanol daun sangitan menunjukan aktivitas anti bakteri terhadap bakteri Eschericia coli dan Salmonella thypi pada konsentrasi $500 \mathrm{mg} / \mathrm{ml}$ masing masing 16,11 mm dan 17,04 mm yang tergolong kuat tetapi jika dibandingkan dengan antibiotik cotrimosazole $10 \mathrm{mg} / \mathrm{ml}$ terlihat diameter hambat ekstrak etanol daun sangitan masih jauh lebih rendah yaitu $30,35 \mathrm{~mm}$ pada bakteri Eschericia coli dan 33,15 mm pada bakteri Salmonella thypi sedangkan ekstrak etanol tidak menunjukan daya hambat.
\end{abstract}

Kata kunci:Skrining Fitokimia, Salmonella thypi, ekstrak daun sangitan, Eschericia coli

\begin{abstract}
Leaves of sangitan (Sambucus javanica Reinw) are often found but noticed. The leaf part of the sangitan plant is used to treat swelling, insecticides, antidiarrheal, antiinfectives, wounds, smoothing the skin as it contains flavonoid chemical compounds, glycosides, anthracton glycosides, saponins, steroids / triterpenoids and tannins. Screening results of ethanol extract of sour leaves (SambucusjavanicaReinw) contain alkaloid compounds, flavonoids, glikosida, antrakinon glycosides, saponins, steroids / triterpenoids and tannins. The extraction of sangitan leaves was done by maceration using 96\% ethanol. Examination of antibacterial activity of ethanol extract of sangitan leaves was done in vitro by diffusion method of wells with concentrations of 500,400,300, 200 and $100 \mathrm{mg} / \mathrm{ml}$. This study used cotrimosazole as a comparator and $96 \%$ ethanol as a negative control. The extract of ethanol leaves sangitan showed anti bacterial activity against bacteria Eschericia coli and Salmonella thypi at concentration $500 \mathrm{mg} / \mathrm{ml}$ respectively $16,11 \mathrm{~mm}$ and 17,04 $\mathrm{mm}$ which is classified strong but when compared with antibiotic cotrimosazole $10 \mathrm{mg} / \mathrm{ml}$ visible diameter of inhibit ethanol extract Leaves sangitan still much lower that is 30,35 $\mathrm{mm}$ in bacterium Eschericia coli and 33,15 mm in Salmonella thypi bacteria whereas ethanol extract do not show inhibitory power.
\end{abstract}

Keywords: Phytochemical Screening, Salmonella thypi, Sebitan leaf extract, Escherichia coli

How to Cite: Dasopang, E.S. 2017, Skrining Fitokimia dan Uji Aktivitas Antibakteri Ekstrak Etanol Daun Sangitan (Sambucus javanica Reinw), Jurnal BioLink, Vol. 4 (1): Hal. 54-62 


\section{PENDAHULUAN}

Tumbuhan yang digunakan untuk pengobatan sangat banyak namun yang mempunyai data ilmiah sedikit. Salah satu tumbuhan yang dikenal dengan memiliki khasiat untuk pengobatan adalah tumbuhan sangitan (Sambucus javanica Reinw) sangatlah perlu diperoleh data ilmiah untuk meyakinkan akan khasiat tumbuhan tersebut. Bagian yang digunakan sebagai obat adalah akar, batang daun dan bunga yang dijemur sampai kering dan disimpan. Kandungan yang dimiliki daun sangitan adalah alkaloid, saponin, flavonoid, beta sitosterol. Daun sangitan ini sangat pahit, kelat berkhasiat menghilangkat pembengkakan, insektisida, diare, antiinfeksi, luka , menghaluskan kulit.

Melihat kandungan kimia dan kegunaan daun sangitan salah satunya sebagai antidiare, maka saya ingin meneliti aktivitas antibakteri daun sangitan terhadap bakteri penyebab diare yaitu Salmonella thypi dan Eschericia coli. Diare sering dianggap gangguan penyakit yang ringan, namun penanganan yang tidak tepat atau terlambat sering kali menimbulkan kematian.

Bakteri Eschericia coli adalah bakteri yang termasuk dalam enterobakteriaceae yaitu kelompok besar batang gram negatif yang heterogen, yang habitat alamiahnya ada di saluran pencernaan manusia dan hewan. Salmonella thypi merupakan bakteri gram negatif, tidak berspora, tanpa fimbria, dan mempunyai flagel peritrik. Infeksi Salmonella thypi terjadi pada saluran cerna dan kadang menyebar lewat peredaran darah keseluruh organ tubuh.

\section{METODE PENELITIAN}

Penelitian dilakukan di Laboratorium Mikrobiologi Fakultas Farmasi Universitas Tjut Nyak Dhien. Waktu penelitian dilakukan selama lebih kurang 4 (empat) bulan terhitung dari bulan Mei 2016 sampai Agustus 2016.

Metode penelitian dilakukan secara eksperimental dan deskriptif. Penelitian eksperimental yaitu untuk mengetahui pengaruh variabel bebas dengan variabel terikat. Dalam penelitian ini yang dimaksud dengan variabel bebas adalah konsentrasi ekstrak etanoll daun sangitan (Sambucus javanica Reinw) dengan konsentrasi 500,400,300,200 dan 100 $\mathrm{mg} / \mathrm{ml}$, sedangkan variabel terikatnya adalah diameter daerah hambat yang diukur dalam satuan milimeter (mm). Penelitian desktiptif dimaksud untuk mengidentifikasi senyawa aktif yang terkandung di dalam daun sangitan menggunakan skrining fitikimia.

Pengambilan sampel daun pandan wangi dilakukan secara purposif yaitu tanpa membandingkan dengan tumbuhan serupa dari daerah lain. Sampel yang digunakan adalah daun sangitan (Sambucus javanica Reinw) yang masih segar yang diambil di desa Sionggang Tengah Kec. Lumban Julu Sumatera Utara.

\section{Prosedur kerja}

Biakan uji mikroba

Biakan bakteri murni Salmonella Typhi dan Escherichia coli diperoleh dari Laboratorium Kesehatan Daerah (LAB.KESDA) Medan. 
Dasopang, E.S, Skrining Fitokimia dan Uji Aktivitas Antibakteri Ekstrak Etanol Daun

Identifikasi tumbuhan

Identifikasi tumbuhan dilakukan di

Herbarium Mendanense (MEDA)

Universitas Sumatera Utara, Medan.

\section{Pengolahan Bahan Simplisia}

Bahan sampel yang di gunakan adalah Daun Sangitan sebanyak $5 \mathrm{~kg}$ yang masih segar, dicuci bersih dengan air mengalir, ditiriskan lalu dikeringkan dalam lemari pengering pada suhu $40^{\circ} \mathrm{C}$ hingga kering. Daun sangitan dianggap kering bila rapuh (diremas menjadi hancur), kemudian daun sangitan kering diserbuk dengan menggunakan blender dan ditimbang berat serbuk keringnya. Serbuk simplisia disimpan dalam wadah tertutup baik terlindung cahaya matahari dan terhindar dari panas.

\section{Pembuatan larutan pereaksi}

Larutan Asam Klorida $2 \mathrm{~N}$

Sebanyak 16,67 $\mathrm{ml}$ asam klorida pekat diencerkan dalam air suling sehingga volume $100 \mathrm{ml}$.

\section{Larutan Asam Sulfat 2N}

Sebanyak 5,4 asam sulfat pekat diencerkan dalam air suling hingga volume $100 \mathrm{ml}$.

\section{Larutan Besi (III) Klorida 1\%}

Sebanyak 1 g besi (III) klorida dilarutkan sedikit demi sedikit dalam asam klorida $0,5 \mathrm{~N}$ dan volume dicukupkan hingga $100 \mathrm{ml}$.

\section{Pereaksi Bouchardart}

Sebanyak 4 gr kalium Iodida dilarutkan dalam air suling kemudian 2 g iodium dilarutkan sedikit demi sedikit kedalamnya, setelah semuanya larut ditambahkan air suling hingga volume $100 \mathrm{ml}$.

\section{Pereaksi Dragendrorff}

Sebanyak 0,85 g bismuth (III) nitrat dilarutkan sedikit demi sedikit dalam asetat glasial hingga volume 100 ml kemudian ditambahkan $40 \mathrm{ml}$ air suling. Pada wadah lain 8 g kalium iodide dilarutkan sedikit demi sedikit dalam air suling hingga voliume $20 \mathrm{ml}$, kedua larutan dicampur sama banyak. Kemudian ditambahkan $20 \mathrm{ml}$ asam asetat glasial dan diencerkan dengan air suling hingg $100 \mathrm{ml}$.

\section{Pereaksi Mayer}

Sebanyak 1,35 g raksa (II) klorida dilarutkan sedikit demi sedikit dalam air suling hingga volume $60 \mathrm{ml}$. Kemudian pada wadah lain sebanyak $5 \mathrm{~g}$ kalium iodida dalam $10 \mathrm{ml}$ air lalu kedua larutan dicampurkan dan volume dicukupkan dengan air suling hingga $100 \mathrm{ml}$.

Pereaksi Molish

Sebanyak $3 \mathrm{~g}$ alfa naftol ditimbang, kemudian dilarutkan dalam asam nitrat $0,5 \mathrm{~N}$ hingga volume $100 \mathrm{ml}$.

\section{Larutan Natrium Hidroksida $2 \mathrm{~N}$}

Sebanyak 8,002 g natrium hidroksida pelet dilarutkan sedikit demi sedikit dalam air suling hingga volume $100 \mathrm{ml}$.

\section{Larutan Timbal (II) Asetat 0,4 M}

Sebanyak 15,17 g timbal (II) asetat dilarutkan sedikit demi sedikit dalam air suling bebas karbondioksida hingga volume $100 \mathrm{ml}$. 


\section{Pembuatan ekstrak}

Pembuatan ekstrak etanol daun sangitan dilakukan dengan metode maserasi menggunakan pelarut etanol 96\%. Caranya 200 g serbuk simplisia dimasukan kedalam sebuah bejana, dituangi dengan $1500 \mathrm{ml}$ etanol etanol 96\% ditutup, dibiarkan selama 5 hari terlindung dari cahaya sambil di aduk. Setelah 5 hari campuran tersebut diserkai. Ampas dicuci dengan etanol 96\% secukupnya ingga diperoleh 2000 ml. Pindahkan kedalam bejana tertutup, dibiarkan ditempat sejuk, terlindung dari cahaya selama 2 hari. Kemudian dienap tuangkan. Dipekatkan dengan alat rotary evaporator pada temperatur tidak lebih dari $50^{\circ} \mathrm{C}$ sampai diperoleh ekstrak semi kental, kemudian diuapkan dengan bantuan penangas air agar hasilnya kental.

\section{Pembuatan konsentrasi uji ekstrak etanol daun sangitan dan cotrimosazole.}

Ekstrak etanol ditimbang $5 \mathrm{~g}$ kemudian dilarutkan dengan etanol sampai dengan $10 \mathrm{ml}$ untuk konsentrasi $500 \mathrm{mg} / \mathrm{ml}$. Setelah itu dilakukan pengenceran 400,300,200 dan 100 $\mathrm{mg} / \mathrm{ml}$. Dan konsentrasi cotrimosazole $10 \mathrm{mg} / 10 \mathrm{ml}$.

\section{Skrining Fitokimia \\ Identifikasi alkaloid}

Identifikasi alkaloid dilakukan dengan metode Mayer, Wagner dan Dragendroff. 0,5 g serbuk simplisia

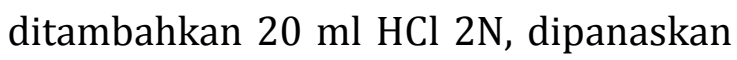
diatas penangas air selama 2 menit, didinginkan dan disaring. Filtrat dibagi menjadi 3 bahagian dan masing masing ditambahkan pereaksi Mayer, Wagner dan Dragendroff.

\section{Identifikasi Flavonoid}

Sebanyak 10 g serbuk simplisia di tambahkan $10 \mathrm{ml}$ etanol, direfluks selama 10 menit, di saring panas melalui kertas saring. Filtrat diencerkan dengan $10 \mathrm{ml}$ aquadest. Setelah dingin ditambahkan $5 \mathrm{ml}$ eter minyak tanah, dikocok hati-hati, lalu didiamkan sebentar.kemudian di ambil lapisan etanol, diuapkan pada suhu $40^{\circ} \mathrm{C}$, sisanya dilarutkan dalam $5 \mathrm{ml}$ etil asetat, disaring. Filtratnya digunakan sebagai larutan uji untuk flavonoid dengan cara sebanyak $1 \mathrm{ml}$ larutan uji diuapkan sampai kering, sisa di larutkan dalam $2 \mathrm{ml}$ etanol 96\%, ditambah 0,1 g serbuk magnesium dan 10 tetes klorida pekat.

\section{Identifikasi tanin}

Sebanyak $1 \mathrm{~g}$ serbuk simplisia di didihkan selama 15 menit dalam $10 \mathrm{ml}$ aquadest lalu didinginkan dan disaring. Filtrat diencerkan sampai hampir tidak berwarna, lalu ditambahkan 1-2 tetes pereaksi $\mathrm{FeCl} 3$ 1\%.

\section{Pemeriksaan Glikosida}

Sedikit serbuk simplisia dimasukan dalam erlenmeyer ditambah etanol sampai terendam, direfluks selama 1 jam, didinginkan dan disaring. Kemudian filtrat ditambahkan timbal (II) asetat 0,4 $\mathrm{M}$ dan aquadest $20 \mathrm{ml}: 20$ $\mathrm{ml}$, didiamkan sampai endapan turun, disaring. Filtrat disari dengan kloroform $18 \mathrm{ml}$ dan isopropanol $12 \mathrm{ml}$ di dalam corong pisah, dikocok sampai terbentuk 2 lapisanyaitu lapisan atas (gula) dan lapisan bawah (non gula).

Lapisan atas:

Sebanyak $1 \mathrm{ml}$ larutan percobaan dimasukan ke dalam tabung reaksi dan diuapkan diatas penangas air selama 
setengah jam. Kemudian ditambahkan 2 $\mathrm{ml}$ air dan 5 tetes pereaksi Molish, kemudian secara perlahan ditambahkan $2 \mathrm{ml}$ asam sulfat pekat melalui dinding tabung, terbentuk cincin warna coklat/coklat keunguan/ungu pada batas antara kedua cairan menunjukan adanya ikatan gula.

Lapisan bawah:

Sebanyak $5 \mathrm{ml}$ kedalam cawan diuapkan sampai kering kemudian ditambahkan 3 tetes asam asetat anhidrida dan 3 tetes asam sulfat pekat. Bila terbentuk warna ungu/ ungu kemerahan menunjukan adanya steroid. Uji glikosida bisa juga dilakukan dengan cara: Sedikit sampel ekstrak etanol dimasukan kedalam tabung reaksi ditambah aquades lalu ditambahkan 5 tetes Fehling A dan 5 tetes Fehling B dipanaskan sampai terbentuk warna bata/kuning jingga.

\section{Pemeriksaan Glikosida Antrakinon}

Sedikit sampel ekstrak etanol dimasukan kedalam erlenmeyer ditambahkan etanol sampai terendam, ditambahkan 2 ml larutan $\mathrm{FeCl} 3$ 1\% ditambahkan asam klorida pekat sampai $\mathrm{pH}$ asam direfluks selama 30 menit setelah mendidih. Setelah dingin, masukan kecorong pisah ditambahkan $10 \mathrm{ml}$ benzen, dikocok ditambah $2 \mathrm{ml}$ larutan $\mathrm{NaOH} 2 \mathrm{~N}$, didiamkan. Lapisan $\mathrm{NaOH}$ bewarna merah menunjukan adanya glikosida antrakuinon.

\section{Identifikasi saponin}

Sedikit sampel ekstrak etanol
dimasukan dalam tabung reaksi,
ditambahkan
didinginkan dan dikocok kuat-kuat
selama 10 detik. Jika terbentuk buih

yang mantap selama kurang lebih 10 menit setinggi $1 \mathrm{~cm}$ sampai $10 \mathrm{~cm}$ dan tidak hilang dengan penambahan 2 tetesasa klorida $2 \mathrm{~N}$ menunjukan adanya saponin.

\section{Identifikasi steroid/triterpenoid}

Sedikit sampel ekstrak etanol dimasukan kedalam erlenmeyer ditambahkan $\mathrm{n}$ heksan sampai terendam direfluks minimal 2 jam, disaring. Filtrat $10 \mathrm{ml}$ dimasukan kedalam cawan porselin diuapkan sampai kering, sisanya ditambahkan pereaksi Liebermann-Bauchard (asam asetat anhidrida 3 tetes dan asam sulfat pekat 3 tetes). Bila terbentuk warna ungu/ungu kemerahan menunjukan adanya triterpenoid sedangkan bila terbentuk warna biru/biru hijau menunjukan adanya steroid.

\section{Pembuatan media}

\section{Media Mueller Hinton Agar (MHA)}

Sebanyak 23 g media Mueller Hinton Agar dilarutkan ke dalam air suling steril yang secara sedikit demi sedikit, kemudian volumenya dicukupkan hingga $1 \mathrm{~L}$ dengan bantuan pemanasan sampai terlarut sempurna. Disterilkan dalam autoklaf pada temperatur $121^{\circ} \mathrm{C}$ selama 15 menit.

\section{Media Nutrien Agar (NA)}

Sebanyak 23 g media nutrien Agar dilarutkan dalam air suling steril kemudian volumenya dicukupkan hingga $1 \mathrm{~L}$ dengan bantuan pemanasan sampai semua bahan terlarut. Disterilkan dalam autoklaf pada temperatur $121^{\circ} \mathrm{C}$ selama $\quad 15$ menit.Setelah media NA disterilkan, masukan sebanyak $5 \mathrm{ml}$ kedalam tabung 
reaksi steril, kemudian diamkan pda temperatur kamar sampai sediaan memadat pada posisis miring kira-kira $45^{\circ} \mathrm{C}$. Kemudian disimpan dalam lemari pendingin $5^{\circ} \mathrm{C}$.Setelah media $\mathrm{NaA}$ mengeras dalam bentuk miring, digoreskan koloni bakteri pada media tersebut dengan menggunakan jarum ose steril. Kemudian diinkubasi dalam inkubator pada suhu $36-37{ }^{\circ} \mathrm{C}$ selama 18-24 jam.

\section{Media Nutrien Broth (NB)}

Ditimbang media Nutrient Broth (NB) sebanyak $8 \mathrm{~g}$, lalu dilarutkan dalam air suling steril sedikit demi sedikit, kemudian dicukupkan volumenya hingga $1 \mathrm{~L}$ dengan bantuan pemanasan sampai semua terlarut sempurna. Disterilkan dalam autoklaf pada temperatur $121^{\circ} \mathrm{C}$ selama 15 menit. Setelah disterilkan didiamkan media hingga dingin, kemudian masukan $10 \mathrm{ml}$ kedalam tabung reaksi steril dan ambil koloni bakteri dari stok kultur dengan menggunakan jarum ose lalu disuspensikan dalam tabung reaksi yang telah berisi $10 \mathrm{ml}$ larutan Nutrien broth. Ukur kekeruhan larutan pada panjang gelombang $580 \mathrm{~nm}$ sampai diperoleh transmitan 25\%( konsentrasi bakteri $1 \times 10^{6} \mathrm{CFU} / \mathrm{ml}$.

\section{Pembuatan Agar miring}

Kedalam tabung reaksi steril dimasukkan sebanyak $3 \mathrm{ml}$ media Nutrien Agar steril, didiamkan pada temperatur kamar sampai sediaan memadat pada posisi miring kira kira kemiringan $45^{\circ} \mathrm{C}$. Kemudian disimpan dalam lemari pendingin .

\section{Pembuatan suspensi standar Mc.Farland}

Larutan asam sulfat $1 \% \quad 9,5 \mathrm{ml}$ ditambahkan larutan barium klorida 1,175\% b/v 0,5 ml dikocok homogen sehingga diperoleh suspensi dengan tingkat kekeruhan yang dikenal dengan standar Mc.Farland.Apabila kekeruhan suspensi bakteri uji sama dengan kekeruhan suspensi standar Mc.farland, maka konsentrasi suspensi bakteri adalah $10^{8} \mathrm{CFU} / \mathrm{ml}$.

\section{Pembuatan inokulum}

Koloni bakteri yang diremajakan pada media NA diambil dari stok kultur dengan menggunakan jarum ose steril, lalu disuspensikan kedalam tabung reaksi yang berisi $10 \mathrm{ml}$ larutan media nutrien broth (NB). Kemudian kekeruhan dibandingkan dengan kekeruhan Mc.Farland makan konsentrasi bakteri $10^{8}$ CFU/ml.Selanjutnya dipipet $0,1 \mathrm{ml}$ suspensi bakteri $10^{8}$ koloni/ml, dimasukan ke dalam tabung reaksi yang berisi $10 \mathrm{ml} \mathrm{NB}$, kocok homogen maka diperoleh suspensi bakteri dengan konsentrasi $10^{6} \mathrm{CFU} / \mathrm{ml}$.

\section{Pengujian antibakteri}

Pengujian antibakteri dilakukan terhadap ekstrak etanol dengan metode difusi agar menggunakan pencadang logam.dengan cara sebanyak 0,1 ml inokulum bakteri dimasukan kedalam cawan petri steril, dituang $20 \mathrm{ml}$ MHA pada suhu $45^{\circ} \mathrm{C}$, kemudian cawan petri digoyang hingga permukaan merata, kemudian dibiarkan sampai media dingin memadat.pada media yang telah padat ditanam cincin pencadang logam dan diatur jaraknya, kemudian pada masing masing pencadang dimasukan 
ekstrak dengan berbagai konsentrasi. Cawan petri dibungkus dengan perkamen dan diinkubasi pada suhu 36$37^{\circ} \mathrm{C}$ selama $18-24$ jam. Setelah 24 jam diukur dameter daya hambat daerah bening yang terbentuk disekitar cincin pencadang logam dengan menggunakan jangka sorong. Pengujian dilakukan sebanyak 3 kali pengulangan

\section{Prosedur Kerja}

Melakukan pengambilan sampel yang mengacu pada Rugayah et al. (2004) dimana diusahakan memperoleh koleksi yang subur (fertil), dan mengambil semua bagian yang ada pada tumbuhan tumbuhan bawah tersebut, mencatat parameter yang terdapat di lapangan, antara lain tempat hidup, warna pada daun, bunga, aroma daun dan lain-lain. Lalu mengoleksi sampel tumbuhan dan memberikan label gantung pada tiap sampel yang dikoleksi, kemudian dibuat menjadi spesimen koleksi dengan meletakkan spesimen di antara kertas koran dan diawetkan dengan alkohol $70 \%$ untuk mencegah kontaminasi jamur dan pembusukan.Setelah pengamatan di lapangan berakhir, tumbuhan bawah yang telah dikoleksi dibuka kembali dan disusun sedemikian rupa untuk dikeringkan dalam oven pengering pada temperatur $\pm 60^{\circ} \mathrm{C}$ selama 24 jam. Setelah spesimen telah benar-benar kering diidentifikasi dengan menggunakan buku-buku identifikasi.

\section{HASIL DAN PEMBAHASAN}

\section{Hasil Ekstraksi Tumbuhan}

Berdasarkan hasil maserasi $200 \mathrm{~g}$ serbuk sangitan dengan etanol $96 \%$ diperoleh ekstrak kental sebanyak 39,7 g. Ekstrak yang diperoleh diuji dengan berbagai konsentrasi terhadap bakteri Escherichia coli dan Salmonella typhi.

\section{Hasil skrining Fitokimia}

Hasil skrining fitokimia menunjukkan hasil alkaloid, tanin, saponin,glikosida, glikosida antrakinon dan steroid/triterpenoid.Senyawa senyaewa tersebut tertarik disebabkan oleh sifat etanol yang memiliki gugus hidriksil polar dan gugus alkil yang bersifat non polar.Menurut Robinson senyawa flavonoid, saponin dan steroid/triterpenoid merupakan senyawa kimia yang memiliki potensi sebagai antibakteri dan antivirus. Senyawa flavonoid yang terdapat di dalam serbuk daun sangitan memanfaatkan gugus alkohol yang mengandung $\mathrm{OH}$ dalam merusak dinding sel, dan penyusun dinding sel bakteri yang terdiri atas peptodoglikan, lipid dan asam amino akan berekasi dengan gugus alkohl pada senyawa flavonoid sehingga dinding sel mengalami kerusakan dan senyawa tersebut dapat masuk ke dalam inti sel bakteri dan berkontak dengan DNA bakteri sehingga sel bakteri mengalami lisis dan bakteri akan mati.

Saponin adalah senyawa aktif kuat yang berperan sebagai antibakteri dengan cara merusak membran sitoplasma sehingga menyebabkan bocornya metabolit yang menginaktifkan sistem enzim bakteri. Kerusakan pada membran sitoplasma dapat mencegah masuknya bahanbahan makanan atau nutrisi yang dibutuhkan oleh bakteri untuk menghasilkan energi dan akibatnya 
bakteri akan mengalami hambatan pertumbuhan dan bahkan kematian. Glikosida yang ditunjukan oleh hasil skrining merupakan glikosida triterpenoid yang mekanisme antibakterinya sama dengan saponin dalam menghancurkan sel bakteri.

Hasil Uji Aktivitas Antibakteri Ekstrak Etanol Daun Sangitan Terhadap Bakteri Escherichia coli dan Salmonella typhi.
Hasil uji aktivitas antibakteri ekstrak etanol daun sangitan (Sambucus javanica Reinw) dengan konsentrasi 500,400,300,200 dan $100 \mathrm{ml}$ dilakukan untuk mengetahui seberapa besar hambatan terhadap bakteri Escherichia coli dan Salmonella typhi pada setiap konsentrasinya dapat dilihat pada grafik dibawah ini.

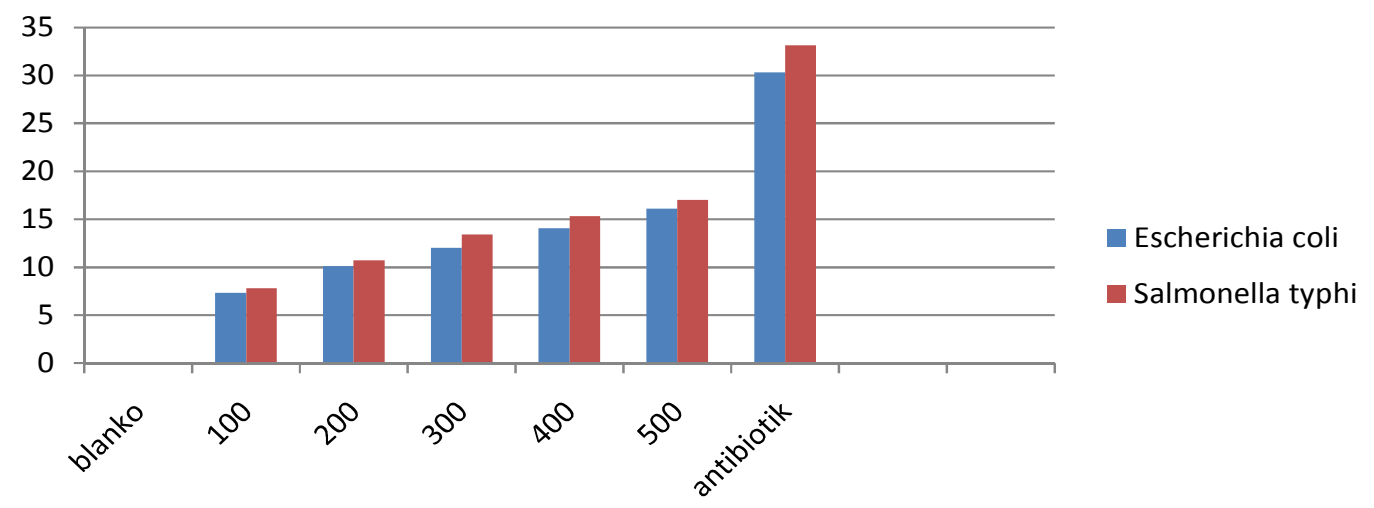

Gambar 1. Hasil pengukuran Diameter hambatan ekstrak etanol daun sangitan terhadap bakteri Escherichia coli dan Salmonela typhi

Hasil uji aktivitas antibakteri pada grafik 1 menunjukan semakin besar konsentrasi ekstrak etanol daun sangitan semakin besar diameter daya hambatan pertumbuhan bakteri Escherichia coli dan Salmonella typhi. Hal ini disebabkan semakin banyak zat aktif antibakteri yang terkandung di dalamnya dengan meningkatnya konsentrasi.. Dari grafik dapat dilihat konsentrasi $500 \mathrm{mg} / \mathrm{ml}$ menunjukan daya hambat untuk bakteri Escherichia coli $16,11 \mathrm{~mm}$, pda konsentrai $400 \mathrm{mg} / \mathrm{ml}$ diameter daya hambar 14,06 mm, konsentrasi 300 $\mathrm{mg} / \mathrm{ml}$ daya hambat sebesar $12,01 \mathrm{~mm}$, pada konsentrasi $200 \mathrm{mg} / \mathrm{ml}$ datya

hambat $10,11 \mathrm{~mm}$ dan pada konsentrasi $100 \mathrm{mg} / \mathrm{ml}$ diameter daya hambat 7,31 $\mathrm{mm}$. Sedangkan diameter daya hambat terhadap bakteri Salmonella typhi dari konsentrasi 500, 400,300,200 dan 100 $\mathrm{mg} / \mathrm{ml}$ adalah $17,04 \mathrm{~mm}, 15,31 \mathrm{~mm}$, $13,43 \mathrm{~mm}, 10,73 \mathrm{~mm}, 7,81 \mathrm{~mm}$. Terlihat diameter hambatan pertumbuhan bakteri Escherichia coli lebih kecil dibanding diameter hambatan pertumbuhan bakteri Salmonella typhi. Berarti ekstrak etanol daun sngitan lebih kuat menghambat bakteri Salmonella typhi dibandingkan Escherichia coli disebabkan kandungan zat aktif yang bersifat antibakteri pada daun sangitan lebih kuat bekerja terhadap bakteri Salmonella typhi.

Jika dibandingkan dengan cotrimosazole $10 \mathrm{mg} / 10 \mathrm{ml}$ terlihat diameter daya hambat ekstrak etanol 
daun sangitan masih sangat rendah.Hal ini disebabkan antibiotik cotrimosazole sudah dalam keadaan muri dan pelarut etanol tidak menunjukan daya hambat terhadap kedua bakteri tersebut.

Berdasarkan Farmakope Indonesia, syarat daerah hambat efektif apabila menghasilkan batas daerah hambat dengan diameter lebih kurang $14 \mathrm{~mm}$. Menurut Fatmawati dan Wiyono kriteria kekuatan daya hambat antibakteri adalah sebagai berikut: diameter zona hambat 5 $\mathrm{mm}$ atau kurang dikategorikan lemah, zona hambat 5-10 mm dikategorikan sedang, 10-20 mm dikategorikan kuat dan lebih dari $20 \mathrm{~mm}$ dikategorikan sangat kuat. Berdasarkan keriteria tersebut ekstrak etanol daun sangitan mempunyai daya hambat kategori kuat.

\section{SIMPULAN}

Berdasarkan hasil penelitian maka diperoleh kesimpulan bahwa hasil skrining fitokimia pada serbuk simplisia daun sangitan (Sambucus javanica Reinw) meninjukan adanya senyawa alkaloid, flavonoid, glikosida, glikosida antrakuinon,saponin, tanin dan triterpenoid. Hasil uji antibakteri menunjukan bahwa ekstrak etanol daun sangitan (Sambucus javanica Reinw) mempunyai aktivitas antibakteri terhadap Escherichia coli dan Salmonella typhi dan semakin besar konsentrasi ekstrak yang digunakan maka semakin besar daya hambat yang dihasilkan.

\section{DAFTAR PUSTAKA}

Adisastomito,W.2007. Faktor Risiko Diare pada Balita di Indonesia: Systematyc Review Penelitian Akademik Bidang Kesehatan Masyarakat, Makara Kesehatanı (11) hal 110
Ardanaruddin,a., Winarsih dan M.Widayat.20o6. Uji Efektifitas Dekok Bunga Belimbing Wuluh (Averrhoa bilimbi) sebagai Antimikroba Terhadap Bakteri Salmonella typhi Secara In vitro. Jurnal Kedokteran Brawijaya. Volume 20 (1) hal 3-7

Badan POM RI.2012. Pedoman Teknologi Formulasi Sediaan Berbasis Ekstrak. Volume 1.hal 13

Dalimartha.S.2007. Atlas Tumbuhan Obat Indonesia .Jilid II. Cetakan Kesembilan. Jakarta: Trubus Agriwidya

Erna.2012. Uji Aktivitas Antibakteri Air Rebusan, Ekstrak Etil Asetat dan Ekstrak Etanol Cacing Tanah Terhadap Bakteri Staphylococcus aureus. Skripsi: Fakultas Farmasi Universitas Tjut Nyak Dhien

Fatima Yanti dan Wiyono.2012.Uji Aktivitas Antibakteri Ekstrak Etanol Daun Mayana(Coleus atropurpureus L) terhadap Staphylococcus aureus, Escherichia coli dan Pseudomonas aeruginosa Secara In vitro.Manado: Fakultas MIPA Universitas Sam Ratulangi

Fauzia.2013.Aktivitas Antibakteri Ekstrak Daging Buah Mahkota Dewa (Phalerimacrocarpa (Scheff) Boerl) Terhadap Bakteri Staphylococcus aureus. Jakarta: Fakultas Farmasi Universitas Indonesia

Kemenkes.2012. Profil Kesehatan Indonesia Tahun 2011.Kemenkes RI.Jakarta.

Kusmayati dan Agustini. 2007. Uji Senyawa Antibakteri dari Mikroalaga(Porphyridium cruentum),J Biod.8(1). Hal 48-153

Reveny,J.2011.Daya Antimikroba Ekstrak dan Fraksi Daun Sirih (piper betle Linn) Jurnal Ilmu Dasar. Volı2(1). Hal 6-12

Robinson,T.1995. Kandungan Organik Tumbuhan Tingkat Tinggi. Penerbit ITB. Bandung.Hal 36-45

Radji,M.2010. Buku Ajar Mikrobiologi Panduan Mahasiswa Farmasi dan Kedokteran.Jakarta:EGC.Hal 110-130

Zulyusri.2013. Keefektifan Daun Sangitan (Sambucus javanica Reinw) sebahai Insektisida Nabati dalam Pengendalian Rayap Tanah (Coptotermes sp). . Prosiding Semirata FMIPA Universitas Lampung. 